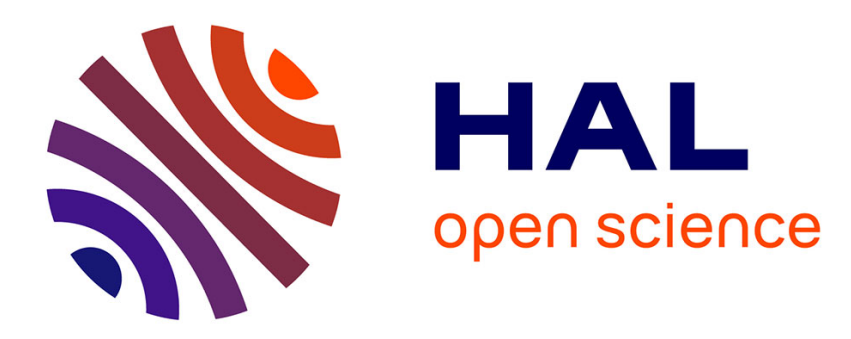

\title{
Leveraged financing, over investment, and boom-bust cycles
}

Patrick-Antoine Pintus, Yi Weng

\section{To cite this version:}

Patrick-Antoine Pintus, Yi Weng. Leveraged financing, over investment, and boom-bust cycles. 2009. halshs-00439245

\section{HAL Id: halshs-00439245 \\ https://shs.hal.science/halshs-00439245}

Preprint submitted on 7 Dec 2009

HAL is a multi-disciplinary open access archive for the deposit and dissemination of scientific research documents, whether they are published or not. The documents may come from teaching and research institutions in France or abroad, or from public or private research centers.
L'archive ouverte pluridisciplinaire HAL, est destinée au dépôt et à la diffusion de documents scientifiques de niveau recherche, publiés ou non, émanant des établissements d'enseignement et de recherche français ou étrangers, des laboratoires publics ou privés. 


\section{Patrick PINTUS Yi WEN}

\section{September 2009}

\footnotetext{
${ }^{1}$ This work was supported by French National Research Agency Grant (ANR-08-BLAN-0245-01).
} 


\title{
Leveraged Financing, Over Investment, and Boom-Bust Cycles*
}

\author{
Patrick A. Pintus \\ Université de la Méditerranée \& GREQAM-IDEP \\ pintus@univmed.fr \\ Yi Wen \\ Federal Reserve Bank of St. Louis \& Tsinghua University (Beijing) \\ yi.wen@stls.frb.org
}

This Version: June 25, 2009 (First Version: May 19, 2008)

\begin{abstract}
It has long been argued in the history of economic thought that over investment through highly leveraged borrowing under elastic credit supply may generate large boombust business cycles. This paper rationalizes this idea in a dynamic general equilibrium model with infinitely lived rational agents. It shows that dynamic interactions between strong asset-accumulation motives (based on habit formation on the borrower side) and elastic credit supply (based on collateralized lending on the lender side) generate a multiplier-accelerator mechanism that can transform a one-time technological innovation into large and long-lasting boom-bust cycles. Such cycles share many features in common to investment bubbles observed in the history (such as the IT bubble in the 1990s and the 2000s housing bubble.).
\end{abstract}

Keywords: Over-Investment, Borrowing Constraints, Multiplier-Accelerator, Elastic Credit Supply.

${ }^{*}$ This is a revised version of an earlier working paper titled "Resuscitating the Credit Cycle." The authors thank Oscar Arce, Costas Azariadis, Jean-Pascal Benassy, Jess Benhabib, Michele Boldrin, Silvio Contessi, Carlos Garriga, Bill Gavin, Rodolfo Manuelli, Adrian Peralta-Alva, Steve Williamson, and seminar participants at several conferences for comments, and Luke Shimek for research assistance. This paper was written while Pintus was visiting the St. Louis Fed, whose hospitality and financial support are gratefully acknowledged. The usual disclaimer applies. Correspondence: Patrick Pintus, Université de la Méditerranée \& GREQAM-IDEP, France. Phone: 334911407 50. Fax: 334919002 27. Email: pintus@univmed.fr. 
JEL codes: E21, E22, E32, E44, E63. 


\section{Introduction}

This paper is a theoretical study on the causes and mechanisms of large boom-bust cycles featuring excessive investment and capital accumulation. We want to know what economic forces can transform a one-time technological innovation or a short period of prosperity into long and large bubble-like booms, and why the "bubbles" eventually burst. We pay attention to the traditional "over investment" theory of the business cycle (e.g., Tugan-Baranovsky, 1894; Wicksell, 1898 and 1906) and ask whether such theory holds water in dynamic general equilibrium where national investment must be financed entirely by domestic savings. A Keynesian economist may argue that periods of persistent consumption growth can foster investment booms and output expansion, which in turn reinforces optimistic outlooks for permanent income and further stimulate consumption demand. So a mild consumption expansion triggered by optimism may turn into prolonged periods of over-expansion. However, in the absence of increasing returns to scale or continuous new technological progress to improve productivity, how is a boom sustainable when consumption crowds out savings yet investment must be financed by savings? The history of economic thought suggests that elastic credit supply from the financial sector may be the culprit. But Tugan and Wicksell's arguments rely on partial equilibrium analysis and, in particular, on the assumption that aggregate investment does not always equal aggregate savings. ${ }^{1}$

We investigate the issue in a general-equilibrium model with heterogeneous agents. We find that when borrowers have strong incentives to accumulate assets and lenders are willing to supply credit elastically, endogenous boom-bust cycles can emerge and such cycles resemble excessive investment and over accumulation of capital during the boom and under investment in the slump. Two factors are needed to support the excessive investment boom in our model. Habit formation or catching-up-with-the-Joneses (CUWJ thereafter) preferences on the borrower side generate a strong incentive to postpone consumption and accumulate wealth in the short run so as to raise consumption in the long run. This encourages capital investment by providing loanable funds. It also generates persistence in consumption growth, which ensures firms' prospect of future sales. In addition, when borrowing is constrained by the value of collateralized assets, the incentives for investment are compounded because undertaking investment

\footnotetext{
${ }^{1}$ Tugan-Baranovsky (1894) argued that industrial cycles were driven by an independent investment function and that, ultimately, over-investment was the cause of recessions. Similarly, Wicksell (1906) proposed making investment independent of savings so aggregate demand is free to rise above or fall below a given level of aggregate supply. For a review of Tugan-Baranovsky's economic theory on business cycles, see Barnett (2001).
} 
improves the borrowers' credit worthiness, which relaxes their future borrowing constraints. These two factors reinforce each other dynamically, generating a cumulative process of expansion once the economy is shocked by good news in the borrowers' productivity. More precisely, the interaction works as follows. Suppose that there is a one-percent unexpected positive shock to total factor productivity (TFP henceforth). At the impact period, the borrower's propensity to save rises substantially because habit formation creates a strong incentive to save the transitory extra income so as to increase consumption in the long run. This motive is reinforced by the borrower's will to borrow and invest so as to relax collateral constraints in the future. The outcome of this investment boom in the next period is that, although the shock is gone, the borrower's stocks of productive inputs rise so much that the effect on output may be several times larger than the initial one-percent TFP increase. Therefore, the impulse response function of output is hump-shaped. In contrast, absent CUWJ, the extra income is consumed rather than saved, which leads to a monotonic impulse response of output with small persistence. However, because of diminishing marginal product of capital, over-investment is not sustainable by aggregate savings and a rising debt level will ultimately erode the borrowers' aggregate demand (consumption and investment), resulting in a collapse of the "bubble" followed by a recession. In the downturn phase, the sluggish behavior of consumption and investment under CUWJ forces the economy to converge back to steady state in a cyclical fashion. Therefore, output falls below its long run level for a while so that a recession inevitably follows the investment boom.

To summarize, the boom-bust cycles are created by a multiplier-accelerator mechanism, which translates a one-time positive technology shock into large and highly persistent movements in aggregate spending and output. At the peak of the expansion, the increases in the capital stock and output are several times larger than their initial responses to the shock, and in the contraction phase, they over-shoot their long-run steady-state level from above. In this process an initial boom plants the seed for a future recession and vice versa.

Our formulation of procyclical credit supply borrows from Kiyotaki and Moore (KM 1997), who have shown that endogenous credit limits based on the value of collateralized assets lead to credit cycles when combined with a particular form of lumpy investment. However, subsequent investigations have found that such a propagation mechanism disappears when embedded into a standard RBC model (see, for example, Kocherlakota, 2000; and Cordoba and Ripoll, 2004).

Our approach overcomes this shortcoming. As in Iacoviello (2005), in our model the financial sector (the lender) does not produce tangible goods. This is consistent with the role of financial institutions in the real world where the major role of banks is to provide loans (credit) rather than directly engaging in goods production. Under collateral constraints, a small transitory 
shock can generate a large response in aggregate output because of the reallocation of productive resources from unproductive agents (the lenders) to the productive but credit-constrained agents (the borrowers). In our model, since lenders do not produce goods, any extension of credit from lenders to borrowers strictly increases aggregate output. This feature captures the fact emphasized by Wicksell that resources (credit or money) hoarded by banks do not contribute to GDP unless they are lent out. In the models of KM (1997) and others, both the borrowers and the lenders produce goods and contribute to aggregate output. Thus, extending credit from lenders to borrowers increases the borrowers' output but decreases the lenders' output. As a result, output of the banking sector is countercyclical and the multiplier effect on aggregate output is dampened. In reality, lending out resources by the banking sector does not reduce the sector's output; if anything, it increases it. ${ }^{2}$

The key distinction between our approach and that of the existing literature is that we focus on the joint role of consumers and investors in creating boom-bust business cycles. ${ }^{3}$ Although its importance in understanding asset returns and consumption behaviors has been well acknowledged in the literature, the role of habit formation in generating boom-bust business cycles has not been fully appreciated and thoroughly analyzed. ${ }^{4}$ In this paper we push this argument further by showing that dynamic interactions between collateralized lending (on the supply side of credit) and CUWJ (on the demand side of credit) create strong incentives for overinvestment and thus lead to boom-bust business cycles. This result is obtained despite strongly diminishing returns to investment, in sharp contrast to KM (1997) and Aghion, Banerjee, and Piketty (1999), who assume linear technologies and constant savings rates. ${ }^{5}$

\footnotetext{
${ }^{2}$ Although financial services are a component of GDP, its share in GDP is trivial. On the other hand, the financial (banking) sector is the single most important asset holder and loanable-funds provider of the economy. The assets and credit resources of this sector are not used for goods production, but for generating loans. In this paper, we model the lenders as providing financial services only, in constrast to KM and Cordoba-Ripoll.

${ }^{3}$ Wicksell (1906) argued that over-investment is the cause, rather than a consequence, of the boom-bust cycles. In particular, he emphasized the gap between the natural rate (determined by the marginal products of assets) and the loan rate as an important mechanism for driving investment booms and slumps. However, Wicksell seems to also have acknowledged that the natural rate must be realizable in terms of revenue; otherwise firms will not undertake investment no matter how high the natural rate is above the loan rate (see Boianovsky, 1995). That is, the marginal product of capital is measurable only in terms of marginal utilities of consumption. This is why in our general-equilibrium model persistent consumption demand (or expected consumption growth) is needed, in addition to any deviations of the natural rate from the loan rate, for triggering the multiplieraccelerator mechanism. This is similar to Wicksell's emphasis on persistent commodity-price increases as a trigger of an investment boom and the credit cycle.

${ }^{4}$ See, e.g., Abel (1990), Constantinides (1990), Campbell and Cochrane (1999), Carroll, Overland, and Weil (2000), Fuhrer (2000), Ljungqvist and Uhlig (2000), Boldrin, Christiano, and Fisher (1997, 2001), Michaelides (2002), Alvarez-Cuadrado, Monteiro, and Turnovsky (2004), and Wen (2009), among others. In this literature, habit formation takes two forms, external and internal. We use the former, which corresponds to catching-upwith-the-Joneses. However, internal habit formation gives similar results because it acts as competition for living standards with one's own historical self. For the early literature on the relationship between habit-formation and cycles, see Ryder and Heal (1973) and their followers.

${ }^{5}$ In the original KM model, the emergence of the credit cycle relies crucially on the interaction between
} 
Collateralized credit lending is not by itself sufficient for generating credit cycles. Without additional savings to provide loanable funds and without anticipated persistent increase in consumption demand, firms do not have a strong enough incentive to over-invest or to expand production capacity excessively, even though doing so can relax their borrowing constraints and improve credit worthiness. Hence, additional incentives for savings and persistent consumption growth through external or internal consumption habits are key.

The literature on business cycles with credit market frictions has shown how financial frictions may generate hump-shaped output dynamics. ${ }^{6}$ Our paper complements the existing studies, as we prove that credit market frictions, when interacted with competition for living standards, create not only hump-shaped dynamics but also highly persistent dampened cycles. Proving the presence of cycles is important because it frees the RBC approach from relying on technological regress (that is, negative TFP shocks) to generate recessions.

Our model still has some shortcomings. First, because our model focuses on over-investment as a possible cause of large bubbles, it does not match the business cycle facts at normal times when there may not exist excessive investment. In particular, investment in our model is excessively volatile compared to regular business cycles. We have checked that capital adjustment costs helps reducing investment volatility while keeping the multiplier-accelerator alive. Allowing for more sectors with some sectors featuring over-investment and others featuring normal-or under-investment may also solve this problem. Second, in order to generate complex eigenvalues in our model, we need not only a strong degree of habit formation, but also a small value of the time discounting factor of the borrower. That is, we need the borrower to be willing to postpone consumption into the future (consumption smoothing under habit formation) yet at the same time impatient. Why this is the case is still somewhat puzzling to us. The only explanation we have is that a high degree of impatience implies a stronger incentive to borrow, thus easing over-investment.

credit constraints and lumpy investment under linear production technologies. A linear technology implies that output moves one-for-one with capital, which enhances the multiplier effect of credit borrowing and investment on output. Lumpy investment implies an uncoupling of the borrowers' aggregate borrowing from their aggregate asset holdings, which generates an accelerator effect in the setup of KM. In contrast, we assume standard CobbDouglas technologies and neoclassical capital accumulation. In fact, the multiplier-accelerator mechanism in our model is much stronger than that under linear technologies and lumpy investment. For example, a one-time increase in productivity can lead to as large as a fivefold increase in aggregate output several periods later in our model with capital and labor, whereas it causes only negligible changes in aggregate output after the impact period in the KM model. In contrast to the existing literature, our results continue to hold even when lenders are risk averse and the share of land in production is very small (e.g., 5 percent or less) despite the fact that land may be the only collateralized asset for the borrower.

${ }^{6}$ As exemplified by the contributions of Bernanke and Gertler (1989), Carlstrom and Fuerst (1997), Krishnamurthy (2003), Cooley, Marimon, and Quadrini (2004), Iacoviello (2005), Campbell and Hercowitz (2006), Boháček and Rodríguez Mendizábal (2007), Christiano, Motto, and Rostagno (2007), and Iacoviello and Neri (2008) among many others. Iacoviello and Neri (2008) estimate a model that shares many similarities with ours but they do not focus on boom-bust cycles. 
The rest of the paper is organized as follows. Section 2 presents a basic general-equilibrium model of credit cycles with reproducible capital. In the model, lenders do not produce goods but own land. Borrowers produce goods by using land, capital and inelastic labor as factors of production. It is shown that this model can generate boom-bust cycles under standard parameter values. Section 3 introduces elastic labor and shows that endogenous labor supply can further amplify the multiplier-accelerator mechanism if the income effect on labor supply is small. Implications of constant-rate tax policies and policy shocks are also analyzed. Section 4 concludes the paper with remarks for future research.

\section{The Basic Model}

\subsection{Structure}

There are two types of agents in the economy, lenders and borrowers. Lenders do not produce, but provide loans (credit) to borrowers. In this sense, lenders serve the role of banks or financial institutions in the economy. The type of credit provided by lenders are one-period loans that can be used to finance consumption and investment. Lenders hold assets and derive utilities from consumption and land, ${ }^{7}$ do not accumulate fixed capital, and use interest income (profits) from payment on previous loans to finance current consumption and land investment. The budget constraint of a representative lender is given by

$$
\tilde{C}_{t}+Q_{t}\left(\tilde{L}_{t+1}-\tilde{L}_{t}\right)+B_{t+1} \leq\left(1+R_{t}\right) B_{t}
$$

where $\tilde{C}$ denotes consumption, $\tilde{L}_{t}$ the amount of land owned by the lender in the beginning of period $t, Q_{t}$ the relative price of land, $B_{t+1}$ the amount of new loans (credit lending) generated in period $t$, and $R_{t}$ the real interest rate. The utility function of the lender is given by

$$
U_{l}(\tilde{C}, \tilde{L})=\frac{\tilde{C}^{1-\sigma_{l}}}{1-\sigma_{l}}+b \frac{\tilde{L}^{1-\sigma_{w}}}{1-\sigma_{w}}, \quad\left\{\sigma_{l}, \sigma_{w}, b\right\} \geq 0
$$

and the time discounting factor is $\tilde{\beta} \in(0,1)$.

Borrowers can produce goods using land and capital. ${ }^{8}$ The production technology is given by

$$
Y_{t}=A K_{t}^{\alpha} L_{t}^{\gamma}, \quad \alpha, \gamma \in(0,1), \alpha+\gamma<1
$$

\footnotetext{
${ }^{7}$ As pointed out in Iacoviello (2005), introducing land in the utility function generates a demand for assets.

${ }^{8}$ Labor is fixed in the basic model. Elastic labor will be introduced into the model in section 3.
} 
where $A$ is TFP, $L$ denotes the amount of land owned by the borrower, and $K$ denotes his capital stock. ${ }^{9}$ Capital is reproducible and the total amount of land is in fixed supply,

$$
L_{t}+\tilde{L}_{t}=\bar{L}
$$

Although it is not essential, we allow land in the model for two purposes: (i) to study asset price movements and their role in affecting the collateral value; and (ii) to keep the model comparable to KM and the following literature. A representative borrower in each period needs to finance consumption $(C)$, land investment $\left(L_{t+1}-L_{t}\right)$, capital investment $\left(K_{t+1}-(1-\delta) K_{t}\right)$, and loan payment that includes both the principal $(B)$ and the interest $(R \times B)$, where $\delta \in(0,1)$ is the depreciation rate of capital. The budget constraint of the borrower is given by

$$
C_{t}+K_{t+1}-(1-\delta) K_{t}+Q_{t}\left(L_{t+1}-L_{t}\right)+\left(1+R_{t}\right) B_{t} \leq B_{t+1}+A K_{t}^{\alpha} L_{t}^{\gamma} .
$$

The momentary utility function of the representative borrower is given by

$$
U_{b}(C)=\frac{\left[C_{t}-\rho \bar{C}_{t-1}\right]^{1-\sigma_{B}}}{1-\sigma_{B}}, \quad \sigma_{B} \geq 0
$$

where $\rho \in(0,1)$ measures the degree of habits in consumption and $\bar{C}$ denotes the average consumption of the borrowers. ${ }^{10}$ Borrowers are assumed to be less patient than lenders; hence, their time discounting factor satisfies $\beta<\tilde{\beta}$.

The borrowing constraint faced by the borrower is

$$
\left(1+R_{t+1}\right) B_{t+1} \leq Q_{t+1} L_{t+1}+\theta(1-\delta) K_{t+1}
$$

where $\theta \in(0,1)$ measures the collateral value of the non-depreciated capital stock. KM assume that reproducible capital does not have collateral value, which corresponds to the case with $\theta=0 .{ }^{11}$ The borrowing constraint imposes that the amount of debt in the beginning of the next period cannot exceed the collateral value of assets owned by the borrower next period. The rationale for this constraint is that, due to lack of contractual enforceability, the lender has incentives to lend only if the loan is secured by the value of the collateral. ${ }^{12}$

\footnotetext{
${ }^{9}$ As in Kiyotaki and Moore (1997), we assume that rental markets for assets do not exist.

${ }^{10}$ The results are similar when habit formation is internalized. We choose to present the external habit model because it is simpler. Our main result also holds under multiplicative habits, as in Abel (1990).

${ }^{11}$ If capital is firm specific, then it has little collateral value on the market. However, our results are not sensitive to the value of $\theta$.

${ }^{12}$ For more discussions on this, see Kiyotaki and Moore (1997) and Kiyotaki (1998).
} 


\section{$2.2 \quad$ Allocation without Borrowing Constraints}

In this subsection, we derive an allocation that obtains in a "first-best" environment with perfect risk sharing, absent the credit constraint (7). ${ }^{13}$ We show that there is no credit cycle. The allocation is equivalent to the solution to the following representative-agent's program:

$$
\max \sum_{t=0}^{\infty}\left\{\beta^{t} \frac{\left[C_{t}-\rho \bar{C}_{t-1}\right]^{1-\sigma_{B}}}{1-\sigma_{B}}+\tilde{\beta}^{t}\left[\frac{\tilde{C}_{t}^{1-\sigma_{l}}}{1-\sigma_{l}}+b \frac{\tilde{L}_{t}^{1-\sigma_{w}}}{1-\sigma_{w}}\right]\right\}
$$

subject to

$$
\begin{gathered}
C_{t}+\tilde{C}_{t}+K_{t+1}-(1-\delta) K_{t} \leq A K_{t}^{\alpha} L_{t}^{\gamma} \\
L_{t}+\tilde{L}_{t} \leq \bar{L}
\end{gathered}
$$

The first-order conditions are given by

$$
\begin{gathered}
\beta^{t}\left[C_{t}-\rho C_{t-1}\right]^{-\sigma_{B}}=\tilde{\beta}^{t} \tilde{C}_{t}^{-\sigma_{l}} \\
\tilde{\beta}^{t} \tilde{C}_{t}^{-\sigma_{l}}=\tilde{\beta}^{t+1} \tilde{C}_{t+1}^{-\sigma_{l}}\left[\alpha \frac{Y_{t+1}}{K_{t+1}}+1-\delta\right] \\
\tilde{\beta}^{t} \tilde{C}_{t}^{-\sigma_{l}} \gamma \frac{Y_{t}}{L_{t}}=\tilde{\beta}^{t} b \tilde{L}_{t}^{-\sigma_{w}}
\end{gathered}
$$

In the limit, because $\tilde{\beta}>\beta$, equation (10) implies $\lim _{t \rightarrow \infty}\left[C_{t}-\rho C_{t-1}\right]^{-\sigma_{B}}=0$ provided that $\lim _{t \rightarrow \infty} \tilde{C}_{t}>0$; which in turn implies that the borrower's consumption level goes to zero in the limit, $\lim _{t \rightarrow \infty} C_{t}=0 .{ }^{14}$ Equation (11) gives the modified golden-rule capital-to-output ratio in the steady state, $\frac{K}{Y}=\frac{\alpha \tilde{\beta}}{1-\tilde{\beta}(1-\delta)}$, where $\tilde{\beta}$ is the inverse of the gross interest rate. The resource constraint (8) implies the lender's consumption-to-output ratio, $\frac{\tilde{C}}{Y}=1-\delta \frac{K}{Y}=$ $1-\frac{\delta \alpha \tilde{\beta}}{1-\tilde{\beta}(1-\delta)}$. Equation (12) implies $\gamma \frac{Y}{L} \tilde{C}^{-\sigma_{l}}=b(\bar{L}-L)^{-\sigma_{w}}$, which uniquely solves for the steady-state allocation of land between the two agents because the left-hand side is decreasing in the borrower's land holding $L, \lim _{L \rightarrow 0} L H S=\infty$, and the right-hand side is increasing in it, $\lim _{L \rightarrow \bar{L}} R H S=\infty$.

In the "first-best" allocation, the dynamics of the model is very similar to that of a standard RBC model. Hence, there is no hump-shaped cyclical propagation mechanism for realistic

\footnotetext{
${ }^{13}$ By "first-best" allocation we mean allocation with perfect risk sharing without borrowing constraints. The results are derived under external habit formation but are similar under internal habit formation.

${ }^{14}$ Since the lender is more patient with a lower discounting rate, we must have $\tilde{C}>C$ in the steady state.
} 
parameter values. To see this, notice that the above program is a standard RBC model with two consumption goods except the relative price of $C$ is infinity in the steady state. Hence, near the steady state we can ignore the weight of the borrower's consumption in the utility function and set $C_{t}=0$. The lender's land $\tilde{L}$ in utility plays the role of leisure and the borrower's land $L$ in the production function plays the role of hours worked. The aggregate land supply $\bar{L}$ is equivalent to time endowment. Therefore, as in a standard RBC model, a onetime shock to productivity will have zero persistence in aggregate output. Replacing external habit formation by internal habit formation does not change this basic feature of standard RBC models. ${ }^{15}$ Although the first-best allocation is derived for simplicity under utilitarian social preferences, we conjecture that cycles are ruled out under more general social welfare functions.

\subsection{Competitive Equilibrium with Borrowing Constraints}

Denoting $\tilde{\Lambda}$ as the Lagrangian multiplier of the constraint (1), the first-order conditions of the lender with respect to consumption, land investment, and lending are given, respectively, by

$$
\begin{gathered}
\tilde{C}_{t}^{-\sigma_{l}}=\tilde{\Lambda}_{t} \\
Q_{t} \tilde{\Lambda}_{t}=\tilde{\beta} Q_{t+1} \tilde{\Lambda}_{t+1}+\tilde{\beta} b \tilde{L}_{t+1}^{-\sigma_{w}} \\
\tilde{\Lambda}_{t}=\tilde{\beta}\left(1+R_{t+1}\right) \tilde{\Lambda}_{t+1} .
\end{gathered}
$$

Denoting $\{\Lambda, \Phi\}$ as the Lagrangian multipliers of constraints (5) and (7), respectively, the first-order conditions of the borrower with respect to consumption, land investment, capital investment, and borrowing are given, respectively, by

$$
\begin{gathered}
{\left[C_{t}-\rho C_{t-1}\right]^{-\sigma_{B}}=\Lambda_{t}} \\
Q_{t} \Lambda_{t}=\beta Q_{t+1} \Lambda_{t+1}+\beta \gamma \frac{Y_{t+1}}{L_{t+1}} \Lambda_{t+1}+Q_{t+1} \Phi_{t}
\end{gathered}
$$

${ }^{15}$ With internalized habit formation, equation (10) becomes

$$
\beta^{t}\left[C_{t}-\rho C_{t-1}\right]^{-\sigma_{B}}-\rho \beta^{t+1}\left[C_{t+1}-\rho C_{t}\right]^{-\sigma_{B}}=\tilde{\beta}^{t} \tilde{C}_{t}^{-\sigma_{l}} .
$$

Equations (11) and (12) will remain the same. Hence, if the borrower's consumption level $C$ goes to zero in the steady state, then the model has the same dynamics as that with external habit. In the steady state, the lender's consumption level must be positive because of a lower discounting factor. Hence, the above equation implies that

$$
\lim _{t \rightarrow \infty}\left\{\left[C_{t}-\rho C_{t-1}\right]^{-\sigma_{B}}-\rho \beta\left[C_{t+1}-\rho C_{t}\right]^{-\sigma_{B}}\right\}=0,
$$

which implies $\lim _{t \rightarrow \infty}\left[C_{t}-\rho C_{t-1}\right]=0$. Hence, $\lim _{t \rightarrow \infty} C_{t}=0$. 


$$
\begin{gathered}
\Lambda_{t}=\beta \Lambda_{t+1}\left[\alpha \frac{Y_{t+1}}{K_{t+1}}+1-\delta\right]+\theta(1-\delta) \Phi_{t} \\
\Lambda_{t}=\beta\left(1+R_{t+1}\right) \Lambda_{t+1}+\left(1+R_{t+1}\right) \Phi_{t} .
\end{gathered}
$$

A competitive equilibrium is a sequence of positive prices $\left\{Q_{t}, R_{t}\right\}_{t=0}^{\infty}$ and positive allocations $\left\{C_{t}, \tilde{C}_{t}, K_{t+1}, L_{t+1}, \tilde{L}_{t+1},\right\}_{t=0}^{\infty}$ such that: (i) $\left\{C_{t}, \tilde{C}_{t}, K_{t+1}, L_{t+1}, \tilde{L}_{t+1},\right\}_{t=0}^{\infty}$ satisfies the firstorder conditions (13)-(19), the transversality conditions, $\lim _{t \rightarrow \infty} \beta^{t} \Lambda_{t} L_{t+1}=0, \lim _{t \rightarrow \infty} \beta^{t} \Lambda_{t} K_{t+1}=$ $0, \lim _{t \rightarrow \infty} \tilde{\beta}^{t} \tilde{\Lambda}_{t} \tilde{L}_{t+1}=0$, and the complementarity condition, $\Phi_{t}\left[Q_{t} L_{t}+\theta(1-\delta) K_{t}-\left(1+R_{t}\right) B_{t}\right]=$ 0 for all $t \geq 0$, given $\left\{Q_{t}, R_{t}\right\}_{t=0}^{\infty}$ and the initial endowments $L_{0} \geq 0, \tilde{L}_{0} \geq 0, B_{0} \geq 0, K_{0} \geq 0$; (ii) The good and asset markets clear for all $t, C_{t}+\tilde{C}_{t}+K_{t+1}-(1-\delta) K_{t}=Y_{t}$ and $L_{t}+\tilde{L}_{t}=\bar{L}$, respectively.

The model has a unique steady-state equilibrium in which the borrower is credit-constrained, i.e., equation (7) binds. In steady state, equation (15) indicates that the interest rate is determined by the lender's time discounting factor, $1+R=\tilde{\beta}^{-1}$. This interest rate of loanable funds is different from the "natural" rate determined by the firm's marginal product of capital. Equation (19) then implies $\Phi=(\tilde{\beta}-\beta) \Lambda>0$, suggesting that the borrowing constraint binds around the steady state. ${ }^{16}$ Equation (18) implies that the capital-to-output ratio is given by $\frac{K}{Y}=\frac{\beta \alpha}{1-\beta(1-\delta)-\theta(1-\delta)(\tilde{\beta}-\beta)}$, which determines (in conjonction with the marginal product of land) the natural rate of interest in the terminology of Wicksell. The natural rate would equal the loanable funds rate if $\beta=\tilde{\beta}$; or, as in the first-best economy, if there exists perfect risk sharing without borrowing constraints. ${ }^{17}$ Notice that the capital-to-output ratio increases with $\theta$, suggesting that borrowing constraints entice consumers to save more than necessary when capital can serve as a collateralized asset. Equation (17) implies $Q=(1-\tilde{\beta})^{-1} \beta \gamma \frac{Y}{L}=\sum_{j=0}^{\infty} \tilde{\beta}^{j} \beta \gamma \frac{Y}{L}$, suggesting that the price of land is determined by the present value of its marginal products. The lender's budget constraint implies $\tilde{C}=\beta \gamma Y+\theta(1-\tilde{\beta})(1-\delta) K$, suggesting that the lender's consumption level is a fraction $\beta \gamma$ of aggregate output plus the average per-period collateral value of capital, $\frac{\theta(1-\delta) K}{\sum_{j=0}^{\infty} \tilde{\beta}^{j}}$. The borrower's budget constraint implies $C+\left(\delta+\frac{\theta(1-\delta)}{\sum_{j=0}^{\infty} \tilde{\beta}^{j}}\right) K+\beta \gamma Y=Y$, where the average collateral value of capital reflects the excess savings on capital accumulation besides depreciation. The second part of the savings, $\beta \gamma Y$, finances the downpayment.

\footnotetext{
${ }^{16}$ In a model similar to ours, Iacoviello (2005) uses numerical methods to show that the probability of a non-binding borrowing constraint is very small even when the model is sufficiently away from the steady state.

${ }^{17}$ The gap between the natural rate and the loan rate in the steady state reflects a premium or wedge created by borrowing constraints.
} 
This indicates that investment deviates from savings because of credit lending. All of the great ratios (e.g., capital-to-output ratio, land-to-output ratio, consumption-to-output ratio) are determined as functions of the model's structural parameters only. Once the steady-state distribution of land is determined, the steady-state values of all other variables are determined through the great ratios. Because equation (17) is the demand curve of land and equation (14) gives the supply curve of land, the steady-state distribution of land across agents is determined uniquely by the implicit equation,

$$
\beta \gamma \frac{Y(L)}{L}=\tilde{\beta} b(\bar{L}-L)^{-\sigma_{w}} \tilde{C}(L)^{\sigma_{l}},
$$

where the left-hand side decreases in $L$ and the right-hand side increases in $L$.

\subsection{Quantitative Implications}

The model's stationary equilibrium path is solved by log-linearizing the model around the steady state. As in KM and others in this literature, ${ }^{18}$ we assume that this is a deterministic economy with perfect foresight and the borrowing constraint always binds. And we examine the dynamics of the model near the steady state after a sudden unexpected shock to TFP.

Calibration. The time period is a quarter. As a benchmark, we set the collateral value of capital $\theta=0$ (in accord with KM), the lender's discounting factor $\tilde{\beta}=0.99$ (implying a $4 \%$ annual interest rate), the rate of capital depreciation $\delta=0.025$, capital's income share $\alpha=0.35$, land share $\gamma=0.05$, and the utility weight parameter $b$ is set so that the steady-state ratio of land allocated between the two types of agents $\frac{\tilde{L}}{L}=1$. The results are not very sensitive to these particular parameter values (i.e., $1-10 \%$ changes in these values give similar results). ${ }^{19}$ The risk aversion parameters for the lender, $\left\{\sigma_{l}, \sigma_{w}\right\}$, determine the volatility of asset prices in the model and are hence left free for experiments. The shape of the impulse responses are sensitive to several parameters, including the degree of habit persistence $\rho$, the borrower's discounting factor $\beta$ and risk aversion $\sigma_{B}$. In general, the stronger the borrower's incentive to borrow, the more likely the credit cycle. In Figure 1, we present two sets of values for the three parameters. In the first set, we choose $\rho=0.9, \beta=0.5, \sigma_{B}=4$, and we assume the shock is i.i.d. In the second set, we choose $\rho=0.95, \beta=0.9, \sigma_{B}=2$, and in this case the shock is persistent with an $A R(1)$ coefficient of $0.9 .^{20}$

\footnotetext{
${ }^{18}$ See, e.g., Kocherlakota (2000), Cordoba and Ripoll (2004a), and Iacoviello (2005).

${ }^{19}$ Under these parameter values, the implied steady-state consumption level of the lender is small, less than $2.5 \%$ of aggregate output.

${ }^{20}$ The parameter values for $\rho$ around 0.9 and 0.95 are consistent with the most recent estimates of habit
} 
Impulse Responses. The impulse responses of the model to a one-time one-percent increase in TFP (i.e., an i.i.d. shock) are graphed in the top row windows in figure 1 and those under persistent shocks in the bottom row windows. The left column windows in figure 1 show the responses of aggregate output $(Y)$, aggregate consumption $(C+\tilde{C})$, aggregate capital formation $\left(K_{t+1}\right)$, and the borrower's land investment $\left(L_{t+1}\right)$ when the lender is risk neutral $\left(\sigma_{l}=\sigma_{w}=0\right)$; and the right column windows in figure 1 show the responses of aggregate output, aggregate consumption, the price of land $\left(Q_{t}\right)$, and the gross interest rate $\left(R_{t}\right)$ when the lender is risk averse: $\sigma_{l}=\sigma_{w}=1$. In the top windows, since it is a one-period shock with zero persistence, any serial correlation in the impulse responses is generated endogenously within the model. In the bottom windows, the hump-shaped dynamics reflect endogenous propagation mechanisms because the TFP shock has only AR(1) monotonic persistence. Regardless of the persistence of the shock, with a risk neutral lender (left column windows), the land price and interest rate in the model are constant; hence, credit-resource reallocations or debt fluctuations are driven by the quantities of collateralized assets. Whereas with a risk averse lender (right column windows), the land possession of both the lender and the borrower becomes constant but the land price fluctuates; hence, credit-resource or debt reallocations are driven by the value of collateralized assets. In either case, changes in the nominal size (total volume) of collateral can formation in the literature; see, e.g., Chen and Ludvigson (2004). 
drive the entire economy to fluctuate through credit lending and investment activities.
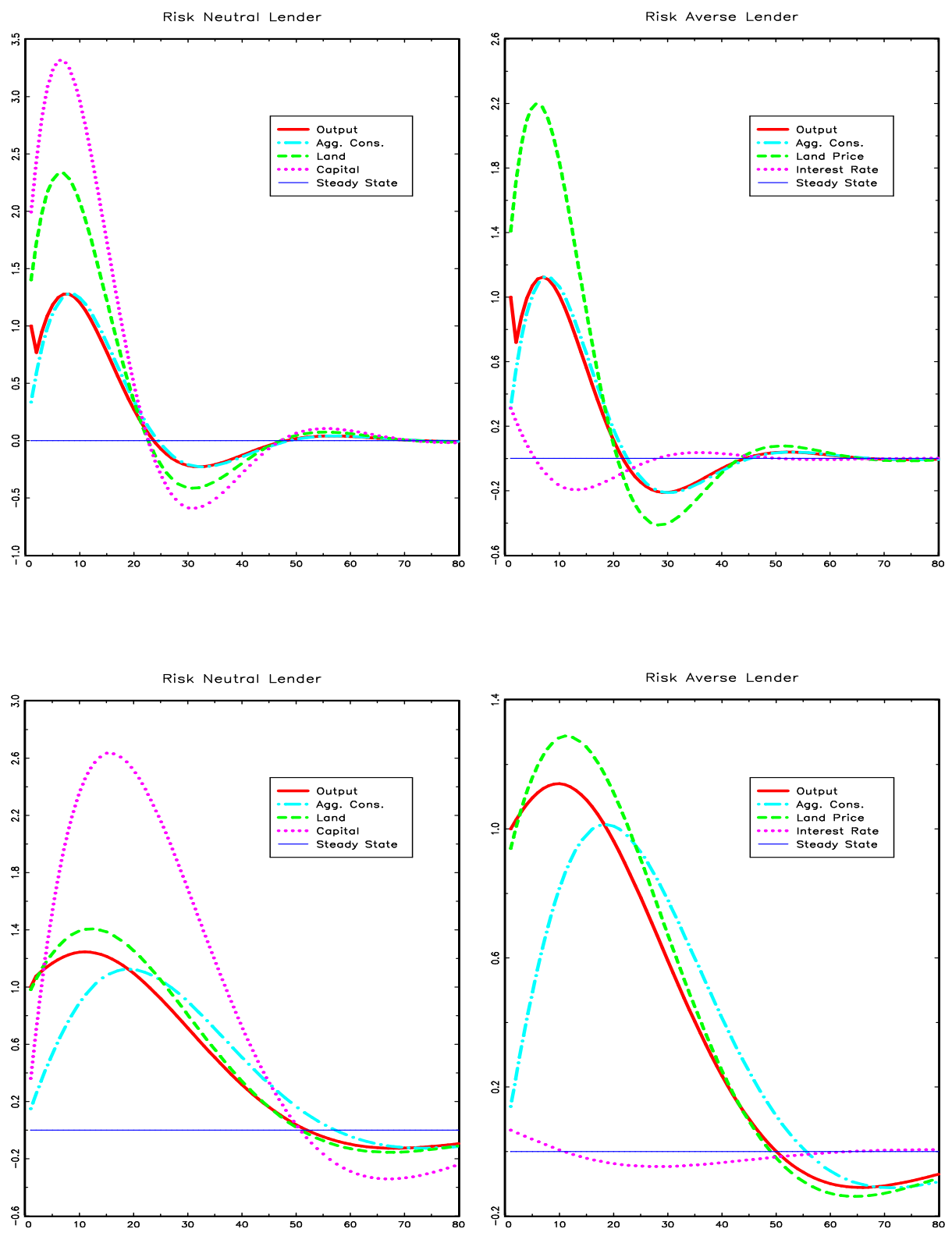

Figure 1. Top: Responses to i.i.d. Shock $\left(\rho=0.9, \beta=0.5, \sigma_{B}=4\right)$. Bottom: Responses to Persistent Shock $\left(\rho=0.95, \beta=0.9, \sigma_{B}=2\right)$.

The top left window in figure 1 shows that a purely transitory shock can generate highly persistent and hump-shaped fluctuations in aggregate activities, due to the presence of stable complex eigenvalues in the linearized system. The dynamic multiplier-accelerator effect on aggregate output reaches its maximum after 6 periods of the shock and the increase in output 
at the peak is about $125 \%$ of the shock itself on TFP. ${ }^{21}$ The economy over-shoots its steady state from above as it retreats from the initial boom and enters a recession before settling down on a long-run steady state via dampened cycles. New capital formation and land investment are excessively volatile and procyclical, suggesting that credit resources are rapidly pumped into the production sector from the financial system, resulting in the typical phenomenon of "over-investment" described by Tugan-Baranovsky (1894) and Wicksell (1906). ${ }^{22}$ The length of each boom-bust cycle is about $10-11$ years long under the current parameterization. ${ }^{23}$ Because the lender is risk neutral, the interest rate and land price do not change over time, albeit the marginal product of capital changes dramatically. ${ }^{24}$

However, the nature of the credit cycle is not sensitive to the degree of risk aversion of the lender. The top right window in figure 1 shows that investment, output, and consumption fluctuate in the same manner with a similar magnitude and cyclical length when the lender's risk aversion parameters are set to $\sigma_{l}=\sigma_{w}=1$. In this case, the quantity of the collateralized asset (land) becomes constant but the land price starts to fluctuate violently, producing cyclical fluctuations in the credit limit and bringing the entire economy to fluctuate along with it.

The above results suggest that fluctuations in land price are not crucial for generating the credit cycle and they weaken the criticism raised against the KM model (see, e.g., the discussion regarding the lack of hedging against movements in land price by Krishnamurthy, 2003). ${ }^{25}$ The multiplier-accelerator mechanism is preserved under the second parameter set as shown in the bottom windows in figure 1. Although the degree of habit formation in both cases is in the upper range of empirical estimates, and the time discounting factor of the borrower is quite low, these parameter values can be further relaxed if we allow endogenous labor supply (see Section 3).

As a comparison, the impulse responses of the "first-best" allocation to a one-time positive shock to TFP are graphed in figure 2, where the parameter values are exactly the same as in the competitive equilibrium (top windows in figure 1) with risk averse lenders (i.e., $\sigma_{l}=\sigma_{w}=1$ ). It shows that the impact of the shock on output is not amplified, and it is short-lived with zero

\footnotetext{
${ }^{21}$ To see the dramatic difference between our model and that of Kiyotaki and Moore (1997), the readers may compare figure 1 with their figure 3 (p.238).

${ }^{22}$ For more discussions on over-investment, see the last paragraph of this subsection.

${ }^{23}$ This cyclical frequency accidently coincides with the length of the business cycles documented by TuganBaranovsky (1894) for 19th century England. Changing the parameter values can also change the length of the cycles in our model.

${ }^{24}$ The response of aggregate output on impact is one percent because all production factors are predetermined and there is no labor. In the second period and beyond, changes in output are completely driven by land and capital accumulations. There is a downward kink in output in the second period because the accumulated asset stocks are not large enough to completely offset the withdraw of the TFP shock.

${ }^{25}$ In fact, we have also experimented with a one-sector model without land and with capital as collateral, in which the price of capital is fixed at unity. The obtained results are similar.
} 
persistence. Although investment is more volatile than output, the capital stock is as smooth as consumption. ${ }^{26}$

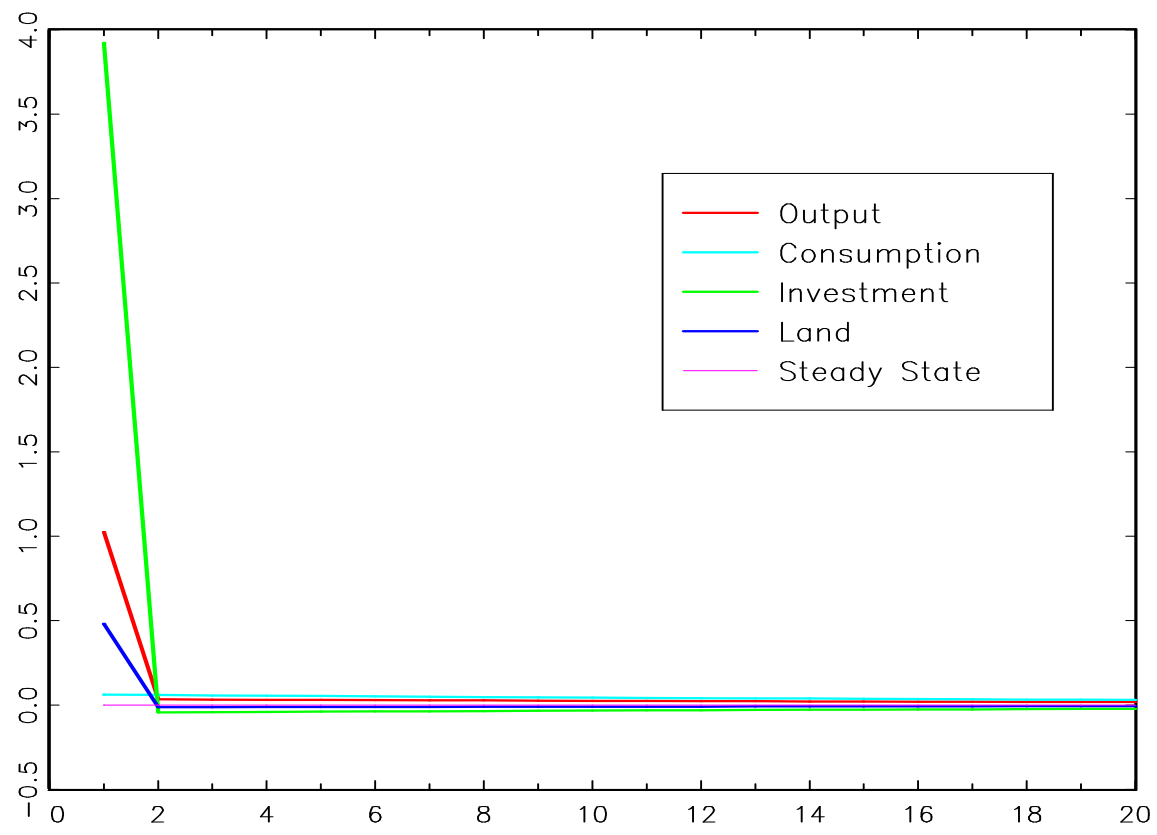

Figure 2. Impulse Responses in a First-Best Allocation.

Over-Investment. Historically, "over-investment" mainly means "investment in excess of savings". Sometimes it also means "excessive investment volatility". Based on the first definition, over-investment is not possible in general equilibrium at the aggregate level in a representative-agent closed economy. However, it is possible in an open economy, or in a closed economy at the disaggregate level for a subset of the agents, if there exist lending and borrowing among the agents (or countries). In our model, over-investment of the non-banking sector (the borrower) is possible and this takes place when investment of the borrower is partially financed by the her own savings and partially by the lender's savings (loans). The borrower's investment is given by $I_{t}=K_{t+1}-(1-\delta) K_{t}+Q_{t}\left(L_{t+1}-L_{t}\right)$, and her savings given by $S_{t}=Y_{t}-C_{t}=\tilde{C}_{t}+K_{t+1}-(1-\delta) K_{t}$. Hence, over-investment takes place if $Q_{t}\left(L_{t+1}-L_{t}\right)>\tilde{C}_{t}$. Thus, whenever land is reallocated from the lender to the borrower in a sufficiently large amount, there exists over-investment. However, in this paper we focus more on the second aspect of the notion of over-investment, namely, excessive investment volatility. ${ }^{27}$

\footnotetext{
${ }^{26}$ As changes of the capital stock, investment is a flow variable and is hence more volatile than capital in percentage terms. The log-linear relationship between investment and capital is given by $i_{t}=\frac{1}{\delta}\left(k_{t+1}-(1-\delta) k_{t}\right)$. In the competitive equilibrium of our model, the capital stock is far more volatile than output, suggesting an even greater volatility of investment. Because movements in other variables appear to be trivial relative to investment, we plot the capital stock instead of investment series in figure 1.

${ }^{27}$ Notice that a larger volatility of investment than that of savings in the log-linear system does not necessarily
} 


\subsection{Sensitivity Analysis}

(i) Endogenous credit limits are important. As emphasized by KM and Kocherlakota (2000), credit limits based on the value of collateralized assets are important for generating an endogenous propagation mechanism. This is also true in our model. We have explored a model with constant credit limits, that is, $\left(1+R_{t+1}\right) B_{t+1} \leq \bar{B}$, and confirmed that there are no multiplier-accelerator effects, hence no hump-shaped credit cycles under standard and empirically plausible parameter values. This is because the supply of credit is no longer elastic and procyclical with a constant credit limit. Consequently, over-investment will not occur because of the lack of the Tugan-Wicksellian credit channel to finance it. However, albeit necessary, endogenous credit limits are not by themselves sufficient for generating the multiplier-accelerator mechanism (more discussions on this point appear below).
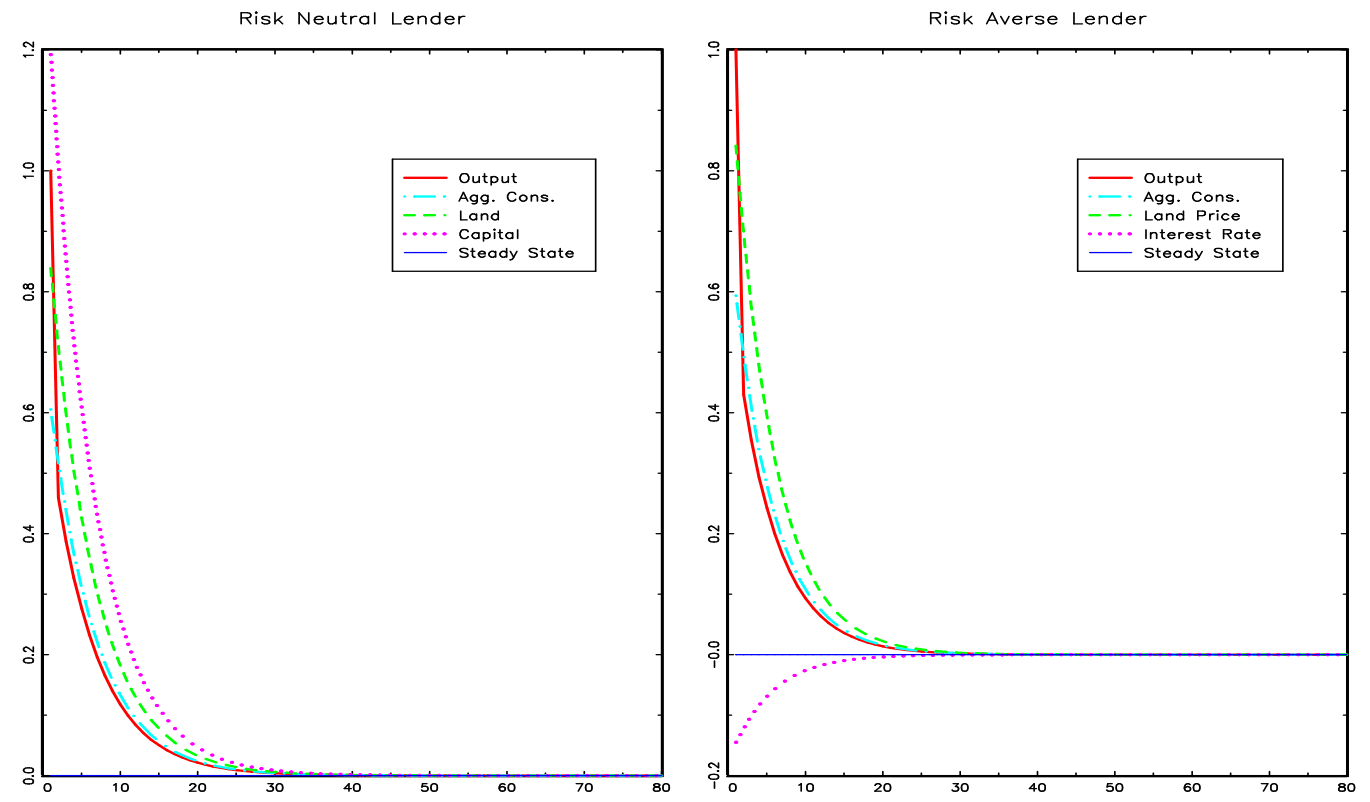

Figure 3. Impulse Responses without Habit Formation $(\rho=0)$.

(ii) Production asymmetry is important. In our model, the lender provides loans but does not produce goods. This asymmetry between the financial role of the lender and the productive role of the borrower is meant to capture the idea of Tugan and Wicksell and is important for the multiplier effect of credit constraints on aggregate output. If the lender also produces goods, as in the model of KM and Cordoba-Ripoll (2004a), then resource reallocation between the lender and the borrower not only generates counter-cyclical fluctuations in lender's output, but

imply investment in excess of savings, because a log-linear variable measures only percentage deviations relative to its own steady state. Although the excessive volatilities of capital and land investment in our model are due to elastic credit supply, they may or may not indicate over-investment (in excess of savings). 
also dampens the magnitude of the cycle so that the peak response of aggregate output to a one-time aggregate TFP shock takes place only in the impact period and the response is less than one-for-one after the impact period. ${ }^{28}$

(iii) Habit formation is important. Without habit formation, the model has no humpshaped credit cycles. For example, setting $\rho=0$ in the basic model leads to monotonic impulse responses as shown in figure $3 .^{29}$

\subsection{Dissecting the Mechanism}

To understand the intuition behind the above results, especially the role played by CUWJ and collateral constraints, consider a simpler version of the basic model where the lender is risk neutral $\left(\sigma_{l}=\sigma_{w}=0\right)$ and there is no capital. Risk neutrality implies a constant interest rate, $(1+R)=\tilde{\beta}^{-1}$, and a constant land price $Q$ according to equations (13)-(15). Equation (19) then becomes $\Phi_{t}=\tilde{\beta} \Lambda_{t}-\beta \Lambda_{t+1}$. Assume $\sigma_{B}=1$ and the borrowing constraint binds:

$$
(1+R) B_{t+1}=Q L_{t+1}
$$

The leverage effect of collateralized borrowing modifies the borrower's budget constraint in the following way:

$$
C_{t}+Q L_{t+1}-\left(Q L_{t}-(1+R) B_{t}\right)=\tilde{\beta} Q L_{t+1}+A L_{t}^{\gamma}
$$

where the third term on the left-hand side vanishes because the borrower sells the current land stock to repay the last-period debt, that is, $Q L_{t}=(1+R) B_{t}$. Therefore, the budget constraint can be rewritten as $C_{t}+Q L_{t+1}=\tilde{\beta} Q L_{t+1}+Y_{t}$, where the right-hand side is the sum of collateralized borrowing and output, while the left-hand side sums up consumption and land expenditure. Finally, the budget constraint simplifies to

$$
C_{t}+Q(1-\tilde{\beta}) L_{t+1}=A L_{t}^{\gamma}
$$

where $Q(1-\tilde{\beta}) L_{t+1}$ is the downpayment required to invest in land: whenever investing $Q L_{t+1}$, the borrower is lent $\tilde{\beta} Q L_{t+1}$. In other words, leveraged lending permits the borrower to finance investment at a level far exceeding his/her own savings because the downpayment is close to zero

\footnotetext{
${ }^{28}$ We have experimented with a variant of Cordoba-Ripoll's (2004a) model in which both the lender and the borrower produce goods and there is habit persistence. Our findings are that such a setting still exhibits the accelerator effects (i.e., it can over-shoot the steady state and have cycles), but, not surprisingly, the multiplier effect is significantly weakened.

${ }^{29}$ The next section shows that when labor supply is elastic, credit cycles occur for lower values of the habit persistence parameter $\rho$. However, $\rho>0$ is still necessary for generating credit cycles.
} 
under our parameterization implying that $\tilde{\beta}$ is close to one. Suppose there is no habit formation $(\rho=0)$, this leveraged lending would imply that the borrower has a strong incentive to raise consumption when income increases, knowing that it is possible to finance investment largely through borrowing. This kills the boom-bust cyclical mechanism by discouraging investment.

To see this analytically, combine the first-order conditions (16)-(17) and (19) by eliminating $\Phi_{t}$, we get

$$
Q(1-\tilde{\beta}) \frac{1}{C_{t}-\rho C_{t-1}}=\beta \gamma \frac{Y_{t+1}}{L_{t+1}} \frac{1}{C_{t+1}-\rho C_{t}}
$$

This equation determines the value of land in the steady state as the present value of the marginal products: $Q=\frac{1}{1-\tilde{\beta}} \beta \gamma \frac{Y}{L}$. Equations (21), (23), and (24) plus a standard transversality condition fully determine the dynamic equilibrium paths of $\left\{C_{t}, L_{t}, B_{t}\right\}$ in this simple model. ${ }^{30}$ When $\rho=0$, the model has closed-form solutions, with the decision rules of consumption, debt, and land investment given by the simple relationships,

$$
\begin{aligned}
C_{t} & =(1-\beta \gamma) A L_{t}^{\gamma}, \\
B_{t+1} & =\frac{\tilde{\beta} \beta \gamma}{(1-\tilde{\beta})} A L_{t}^{\gamma}, \\
L_{t+1} & =\frac{\beta \gamma}{(1-\tilde{\beta}) Q} A L_{t}^{\gamma} .
\end{aligned}
$$

Notice that all decision variables are proportional to aggregate output. Log-linearizing the decision rules around the steady state gives $c_{t}=b_{t+1}=l_{t+1}=\gamma l_{t}$, where lower-case variables denote percentage deviations from the steady state. In this case, a one-percent increase in current output leads to a one-percent increase in the levels of both consumption and new debt, which in turn translates into a one-percent increase in land stock $\left(L_{t+1}\right)$ and a $\gamma$-percent increase in the next period's output. Thus, with the borrower as the single producer in the economy, a one-time shock to TFP can generate serially correlated movements in aggregate output with the degree of persistence determined by $\gamma$. This roughly explains the result obtained by Kocherlakota (2000) and Cordoba and Ripoll (2004a).

However, the $\gamma$-persistence is monotonic and there do not exist hump-shaped boom-bust cycles in the simple model without either habits or CUWJ effect. That is, endogenous credit constraints, by themselves, generate endogenous persistence but do not give rise to the humpshaped multiplier-accelerator mechanism, unless, as shown by KM, a particular form of lumpy investment is introduced.

\footnotetext{
${ }^{30}$ The lender's consumption level is simply determined by interest income.
} 
In order to generate a more persistent and hump-shaped propagation mechanism, we need a larger fraction of the income to be saved and invested in each period, rather than being consumed. This is why the picture changes dramatically when there is habit formation $(\rho>0)$. Habit formation creates a strong incentive for the borrowers to save the transitory income so as to increase future consumption in the long run. With habit formation, agents are more interested in consumption growth than in the consumption level. Hence, after a TFP shock to income, the borrowers increase their marginal propensity to save, which provides more loanable funds for investment. This motive for wealth accumulation is reinforced by the borrowers' desires to borrow under the collateralized lending, thus they opt to invest as much as possible not only to ensure future consumption growth but also to raise the collateral value so as to further reduce the borrowing constraint. To see this, note that equation (24) indicates that with $\rho>0$ and holding tomorrow constant, a one-percent increase in consumption today due to a one-percent increase in income is no longer optimal because it decreases the left-hand side of (24) by more than one percent (due to the habit stock $\rho C_{t-1}$ ) while the right-hand side would decrease by less than one percent after land investment $\left(L_{t+1}\right)$ raises by one percent (due to the rise in the habit stock $\rho C_{t}$ ). Hence, to reach an equilibrium, consumption should increase by less than one percent and land investment should increase by more than one percent. This higher investment level will bring about not only more output next period but also more credit by relaxing the borrowing constraint in the current period. Thus, the incentive for saving under habit formation and the motives for investment under leveraged lending start to reinforce each other dynamically, making possible a cumulative process of output expansion and investment boom that underlies a persistent and hump-shaped propagation mechanism.

However, because of diminishing marginal product of capital, over-investment is not sustainable by aggregate savings and a rising debt level will ultimately erode the borrowers' aggregate demand (consumption and investment), resulting in a collapse of the "bubble" followed by a recession. In the downturn phase, the sluggish behavior of consumption and investment under CUWJ forces the economy to converge back to steady state in a cyclical fashion. Therefore, output falls below its long run level for a while so that a recession inevitably follows the investment boom. This multiplier-accelerator cyclical mechanism can be cast more formally in the following proposition.

Proposition 1 Consider the model without capital $(\alpha=\delta=0)$, with a risk-neutral lender $\left(\sigma_{l}=\sigma_{w}=0\right)$ and logarithmic utility for the borrower $\left(\sigma_{B}=1\right)$. Then there exists a threshold $\bar{\rho} \in(0,1)$ such that if $\rho>\bar{\rho}$, then output amplification to a one-time TFP shock is larger than one; and it approximately equals $1 / \beta>1$ if $\rho$ is close enough to one. In addition, the linearized 
system has a pair of stable, complex eigenvalues.

Proof. The log-linearized dynamics obtained from equations (16), (23), and (24) are given by:

$$
\begin{gathered}
\lambda_{t+1}=\lambda_{t}+(1-\gamma) l_{t+1} \\
c_{t}=\rho c_{t-1}-(1-\rho) \lambda_{t} \\
(1-\beta \gamma) c_{t}+\beta \gamma l_{t+1}=\gamma l_{t}
\end{gathered}
$$

Equation (29) tells us that $c_{t} \approx c_{t-1}$ when $\rho \approx 1$, which means that $c_{1} \approx c_{0}=0$. On the other hand, (30) gives $\beta \gamma l_{2}=\Delta-(1-\beta \gamma) c_{1}$, where $\Delta$ is the initial TFP shock in period one. Therefore, neglecting $c_{1}$, one gets that $\gamma l_{2} / \Delta=1 / \beta$, that is, $y_{2} / \Delta=1 / \beta>1$. By continuity, therefore, there exists a threshold value $\bar{\rho}$ such that output amplification is larger than one provided that $\rho>\bar{\rho}$. In addition, it is not difficult to show, by manipulating the associated characteristic polynomial, that equations (28)-(30) have a pair of stable, complex eigenvalues if $\rho>\bar{\rho}$.

\section{$3 \quad$ Introducing Elastic Labor}

This section introduces endogenous labor by allowing borrowers to supply hours worked elastically. Because habit formation induces a strong negative income effect with standard separable preferences, labor supply decreases after a positive TFP shock. This is inconsistent with the data. In contrast, the absence of income effects ensures that labor is procyclical, in accord with the US data. For this reason, we follow Greenwood, Hercowitz, and Huffman (1988) by adopting the following utility function with no income effect:

$$
\frac{1}{1-\sigma_{B}}\left[C_{t}-\rho \bar{C}_{t-1}-P_{t} \frac{N_{t}^{1+\eta}}{1+\eta}\right]^{1-\sigma_{B}}, \quad \eta \geq 0
$$

where $P$ is the population size of the representative family of borrowers, $N$ hours worked for each member of the family, and $C$ the family's total consumption. ${ }^{31}$ This type of utility function without income effect on labor supply is widely used in the RBC literature. ${ }^{32}$ Taking the normalization $P=1$, the aggregate production function is given by

$$
Y_{t}=A K_{t}^{\alpha} L_{t}^{\gamma} N_{t}^{1-\alpha-\gamma} .
$$

\footnotetext{
${ }^{31}$ We assume perfect risk sharing among family members.

${ }^{32}$ See, e.g.,Greenwood et al. (1988), Mendoza (1991), Correia et al. (1995), Perri and Neumeyer (2005), and Jaimovich and Rebelo (2008).
} 
The first-order condition with respect to hours worked is given by

$$
N_{t}^{\eta}=(1-\alpha-\gamma) \frac{Y_{t}}{N_{t}}
$$

which shows that labor supply depends only on the real wage (the marginal product of labor) and not on consumption. The elasticity of labor supply is $\frac{1}{\eta}$. Based on this first-order relationship, the steady state utility level is strictly positive only if the inequality, $(1+\eta)(1-\rho)>$ $(1-\alpha-\gamma) \frac{Y}{C}$, holds; which imposes constraints on the values of $\rho$ and $\eta$. For example, if $\rho$ is close to one, then $\eta$ must be very large. This model reduces back to the basic model with fixed labor if $\eta=\infty$.

\subsection{Competitive Equilibrium}

To facilitate comparison, all common parameters are set at exactly the same values as those in the basic model of section 2 (top windows in figure 1), which imply labor's share $(1-\alpha-\gamma)=$ 0.6. The elasticity parameter of labor supply is set at $\eta=6$, implying a labor supply elasticity of 0.17 , which is consistent with the microeconomic literature's finding of a relatively small labor supply elasticity. Reducing $\eta$ (increasing the elasticity of labor supply) further will make the multiplier-accelerator effect even stronger and more dramatic, and the system may converge to a Hopf limit cycle as $\eta$ tends to zero. On the other hand, increasing $\eta$ (reducing the labor supply elasticity) reduces the multiplier-accelerator effect and in the limit as $\eta$ tends to infinity, 
the system converges back to the basic model presented above.
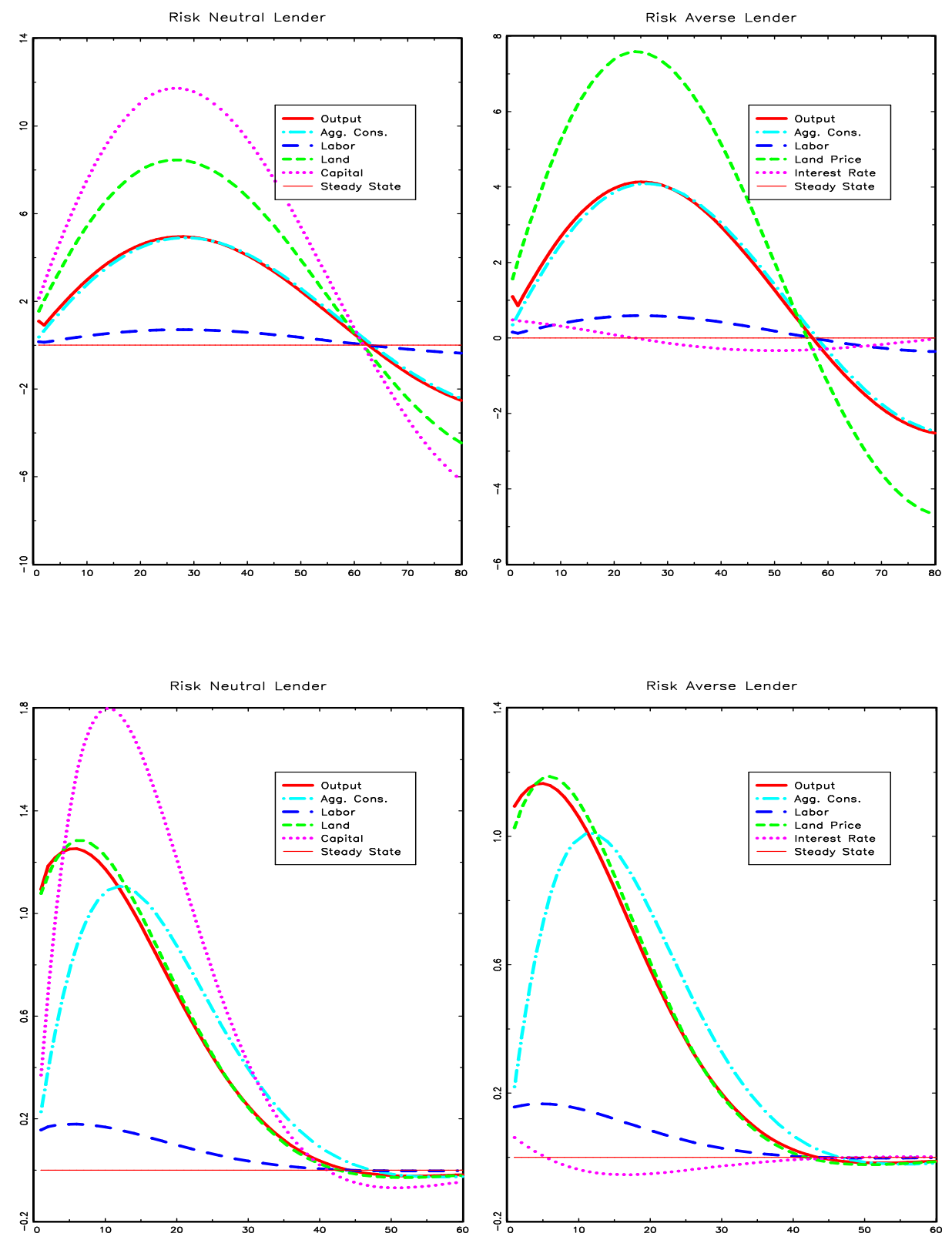

Figure 4. Top: Responses to i.i.d Shock $\left(\rho=0.9, \beta=0.5, \sigma_{B}=4\right)$. Bottom: Responses to Persistent Shock $\left(\rho=0.85, \beta=0.9, \sigma_{B}=1\right)$.

With endogenous labor, the multiplier-accelerator mechanism of collateral constraints is amplified, as shown in the top windows of figure 4. The peak response of output is larger and the length of the cycle is longer. For example, with $\eta=6$, the peak response of output is 5 times the size of the shock and it is reached 28 periods ( 7 years) after the impact period. The length of the cycle is around 120 periods (30 years). Also, the recession following the initial 
boom period is longer and more pronounced.

The nature of the multiplier-accelerator can be adjusted by varying the borrower's incentives to borrow. For example, if the borrower is less risk averse, less habit forming in consumption, or more patient, then the length of the cycle and the magnitude of the hump are altered. As an example, the bottom windows in figure 4 graph the impulse responses of the model when the borrower's risk aversion parameter is set to $\sigma_{B}=1$, habit persistence $\rho=0.85$, and time discunting $\beta=0.9$. With an $\operatorname{AR}(1)$ coefficient of 0.9 , then the peak of the first hump in the responses of aggregate output is reached only after 3 periods and the length of the cycle is much shorter than before, despite the shock is persistent.

\subsection{Policy Implications}

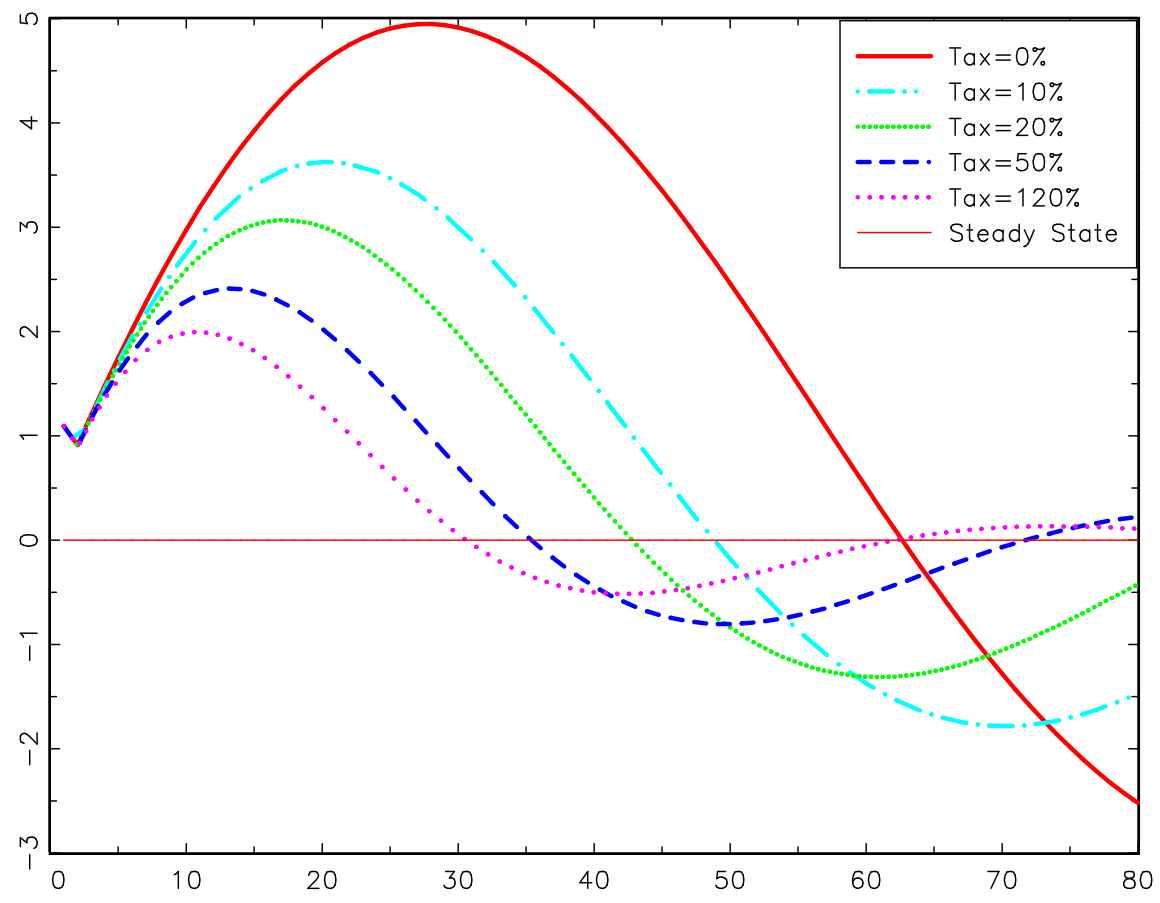

Figure 5. Stabilization Effects of a Consumption Tax.

If optimal stabilizing policies exist, they must be time varing in nature (see our working paper, Pintus and Wen, 2008). However, such complex optimal tax rules are difficult to implement. What we observe in reality are most often simple tax policies, such as constant-rate sales tax. What are the effects of such simple policies? Figure 5 shows the impulse responses of aggregate output (in the economy with labor and risk neutral lender as in top windows in figure 4) to a one-time TFP shock under different steady-state consumption tax rates. The results show that as the tax rate increases, aggregate output is gradually stabilized with smaller 
amplification and reduced persistence. Therefore, a constant-rate consumption tax does have stabilization effects when the tax rate is high enough. The intuition for the stabilization effect is that consumption tax discourages consumption demand, which reduces the incentive for borrowing, hence mitigating the multiplier-accelerator effects of the credit constraints on investment. Similar results can also be obtained under income tax policies.

However, simple tax policies cannot achieve the "first-best" allocation, more often they also introduce further distortions into the economy. As an example, we examine the business cycle effects of a sudden, unexpected, (one-period) 1\% income-tax cut on the competitive economy with labor. Such a tax reduction is meant to boost the economy by increasing the after-tax marginal rates of return to work and investment. However, we show that such policies intended to stimulate the economy can be counter-productive and generate a long-period of recession instead of a boom.

Consider a standard income tax $\tau$ on aggregate output $Y$. The borrower's resource constraint becomes

$$
C_{t}+Q_{t}\left(L_{t+1}-L_{t}\right)+K_{t+1}-(1-\delta) K_{t}+\left(1+R_{t}\right) B_{t} \leq B_{t+1}+\left(1-\tau_{t}\right) A K_{t}^{\alpha} L_{t}^{\gamma} N_{t}^{1-\alpha-\gamma}+T_{t},
$$

where $T=\tau Y$ is a lump-sum transfer payment. Suppose the steady-state income tax rate is $20 \%$; then a one-percent sudden decrease in the income tax rate has the following dynamic effects shown in figure 6 :

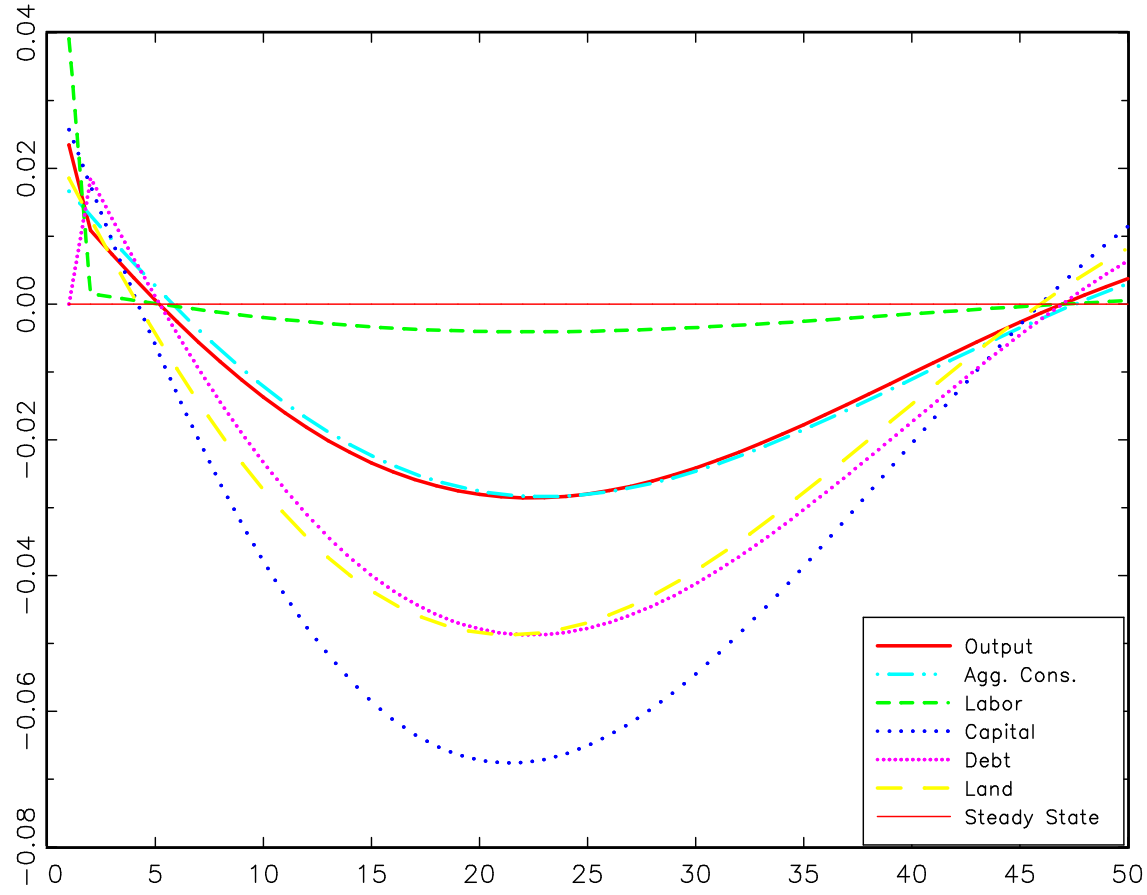

Figure 6. Impulse Responses to an Income-Tax Cut. 
The intuition for the prolonged recession caused by a tax cut is as follows. Initially, a tax cut increases the incentives for working and investing. Hence, there is a short boom in the initial period in aggregate consumption, investment, labor, and output. However, since TFP has not changed, the increase in output is fully due to higher labor supply. Also, because the tax cut is financed by an equal decrease in the lump-sum transfer, the initial increase in aggregate demand is supported heavily by borrowing. Therefore, the debt level increases sharply in the second period and it chokes off investment because the natural rate is below the loan rate. As investment decreases in the second period, the multiplier-accelerator mechanism kicks in and generates a cumulative process of contraction. Therefore, the stimulative package of a tax cut is counter-productive.

\section{Conclusion}

The history of economic thought has long suggested that boom-bust business cycles may be driven by over-investment fueled by credit expansion. Tugan-Baranovsky (1894) argued that industrial cycles were driven by an independent investment function and that, ultimately, overinvestment was the cause of recessions. Similarly, Wicksell (1906) proposed making investment independent of savings so aggregate demand is free to rise above or fall below a given level of aggregate supply. A common theme of this line of economic reasoning is to emphasize the important role of credit. However, in general equilibrium, income stimulates consumption, consumption reduces savings, yet investment requires savings to finance. Hence, boom-bust cycles featuring simultaneous increases in consumption and investment (i.e., co-movements) and their collapses are difficult to generate in standard general-equilibrium models without periodic movements in TFP. Using a two-agent RBC model featuring a productive borrower who is credit-constrained but has a strong incentive to accumulate wealth by saving and an unproductive lender who hoards idle resources but is willing to lend, this paper shows that dynamic interactions between the two forces create a boom-bust cyclical mechanism that embodies some of the ideas and insights of Tugan-Baranovsky and Wicksell.

Habit formation or CUWJ preferences induce highly persistent consumption growth under income shocks. With the interest rate of loanable funds below the household's time discount rate, this leads to strong incentives for asset accumulation not only through savings but also from external borrowing. Because of endogenous credit constraints, firms also have incentives to invest in productive assets, which enhances their credit worthiness, enabling them to borrow even more both in the current and in the future periods so as to meet persistent demand for consumption (sales) growth. The supply of credit reallocates resources from unproductive 
agents to productive agents; hence, it enhances aggregate productivity and fulfills the initial desire for wealth accumulation from households, leading to a cumulative process of output expansion and investment boom. ${ }^{33}$ However, as the expansion continues, the debt level rises persistently while the marginal product of assets diminishes quickly. The rising debt level and the growing costs of borrowing erode the available funds for investment, eventually putting an end on the boom and setting off a contraction. The contraction process accelerates itself towards the steady state because less investment implies less collateral, which implies less credit-worthiness and less loans; in addition, excessive consumption smoothing implies that less consumption today leads to less consumption tomorrow, which further reduces incentives for wealth accumulation and investment demand. Thus, an important feature of the contraction process is the lack of sufficient aggregate demand and sharp drop in investment. This process will continue until a point where the marginal product of assets is significantly higher than its steady-state level and the interest rate so that borrowing and investment become profitable again. ${ }^{34}$ Thus, under the interaction between wealth accumulation and procyclical credit supply, a small shock can trigger a process of boom-bust cycles in credit lending and aggregate activities. In this process, credit resources are unleashed out from the banking sector to the public during an expansion, and sucked back to the banking sector during a contraction. ${ }^{35}$

Our results reinforce the findings of Kiyotaki and Moore (1997) that highly elastic credit supply has devastating consequences. This may help explaining not only why developing countries (where the supply of credit is severely constrained yet at the same time highly elastic because of endogenous credit limits, insider dealing, corruption, weak corporate governance, and speculative international capital flows) are more volatile and susceptible to economic crises than developed countries, but also why lowered credit standards in the subprime mortgage market designed to meet persistent housing demand for low-income households could have been responsible for the recent financial turmoil in the U.S.

Our model may be viewed as a prototype for many possible extensions. For example, asset pricing, the housing market, oil shocks, sticky prices, monetary policies, imperfect competition, international trade, small-open economy, and so on, can be embedded into our model to study their implications for boom-bust cycles.

\footnotetext{
${ }^{33}$ Without the excessive consumption-smoothing motive, the initial rise in income would be consumed rather than saved to finance investment.

${ }^{34}$ Neither Tugan-Baranovsky (1894) nor Wicksell (1906) had a formal theory of the turning points of the business cycle, although Wicksell conjectured that the fluctuations in the marginal product of capital were important for understanding the turning points.

${ }^{35}$ This process of credit cycles was visualized by Tugan-Baranovsky (1894) as the motion of a steam engine. When the pressure of the steam attained a certain level, the resistance of the piston was overcome and it was set in motion, before returning again to its original position when the steam was exhausted (Barnett, 2001).
} 


\section{References}

[1] Abel A., 1990. Asset prices under habit formation and catching up with the Joneses. American Economic Review 80(2), 38-42.

[2] Aghion, P., Banerjee, A., Piketty, T., 1999. Dualism and macroeconomic volatility. Quarterly Journal of Economics 114(4), 1359-97.

[3] Alvarez-Cuadrado, F., Monteiro, G., Turnovsky, S., 2004. Habit formation, catching up with the Joneses, and economic growth. Journal of Economic Growth 9(4), 47-80.

[4] Barnett, V., 2001. Tugan-Baranovsky as a pioneer of trade cycle analysis. Journal of the History of Economic Thought 23(4), 443-466.

[5] Bernanke, B., Gertler, M., 1989. Agency costs, net worth, and business fluctuations. American Economic Review 79(1), 14-31.

[6] Boháček, E., Rodríguez Mendizábal, H., 2007. Credit markets and the propagation of monetary policy shocks. Journal of Money, Credit and Banking 39(6), 1429-1455.

[7] Boianovsky, M., 1995. Wicksell's business cycle. European Journal of the History of Economic Thought 2(2), 375-411.

[8] Boldrin, M., Christiano, L., Fisher, J., 2001. Habit persistence, asset returns, and the business cycle. American Economic Review 91(1), 149-166.

[9] Campbell, J., Cochrane, J., 1999. By force of habit: a consumption-based explanation of aggregate stock market behavior. Journal of Political Economy 107(2), 205-251.

[10] Campbell, J., and Hercowitz, Z., 2006. The role of collateralized household debt in macroeconomic stabilization. NBER Working Papers 11330.

[11] Carlstrom, C., Fuerst, T., 1997. Agency costs, net worth, and business fluctuations: a computable general equilibrium analysis. American Economic Review 87(5), 893-910.

[12] Caroll, C., Overland, J., Weil, D., 2000. Saving and growth with habit formation. American Economic Review 90(3), 341-355. 
[13] Chen, X., Ludvigson, S., 2004. Land of addicts? An empirical investigation of habitbased asset pricing behavior. NBER Working Papers 10503. Forthcoming in the Journal of Applied Econometrics.

[14] Christiano, L., Motto, R., Rostagno, M., 2007. Financial factors in business cycles. Mimeo Northwestern University.

[15] Constantinides, G.M., 1990. Habit formation: a resolution of the equity premium puzzle. Journal of Political Economy 98(3), 519-543.

[16] Cooley, T., Marimon, R., Quadrini, V., 2004. Aggregate consequences of limited contract enforceability. Journal of Political Economy 112(4), 817-847.

[17] Cordoba, J.-C., Ripoll, M., 2004a. Credit cycles redux. International Economic Review 45(4), 1011-1046.

[18] Cordoba, J.-C., Ripoll, M., 2004b. Collateral constraints in a monetary economy. Journal of the European Economic Association 2(6), 1172-1205.

[19] Correia, I., Neves, J., Rebelo, S., 1995. Business cycles in a small open economy, European Economic Review 39(6), 1089-1113.

[20] Fuhrer, J., 2000. Habit formation in consumption and its implications for monetary-policy models. American Economic Review 90(3), 367-390.

[21] Greenwood, J., Hercowitz, Z., Huffman, G., 1988. Investment, capacity utilization, and the real business cycle. American Economic Review 78(3), 402-417.

[22] Iacoviello, M., 2005. House prices, borrowing constraints, and monetary policy in the business cycle. American Economic Review 95(3), 739-764.

[23] Iacoviello, M., Neri, S., 2008. Housing market spillovers: evidence from an estimated DSGE model. Boston College Working Papers in Economics 659.

[24] Jaimovich, N., Rebelo, S., 2008. Can news about the future drive the business cycle? NBER Working Papers 12537. Forthcoming in the American Economic Review.

[25] Kiyotaki, N., 1998. Credit and business cycles. Japanese Economic Review 49(1), 19-36.

[26] Kiyotaki, N., Moore, J., 1997. Credit cycles. Journal of Political Economy 105(2), 211-248. 
[27] Kocherlakota, N., 2000. Creating business cycles through credit constraints. Federal Reserve Bank of Minneapolis Quarterly Review 24(3), 2-10.

[28] Krishnamurthy, A., 2003. Collateral constraints and the amplification mechanism. Journal of Economic Theory 111(2), 277-292.

[29] Ljungqvist, L., Uhlig, H., 2000. Tax policy and aggregate demand management under catching up with the Joneses. American Economic Review 90(3), 356-366.

[30] Matsuyama, K., 2007. Credit traps and credit cycles. American Economic Review 97(1), 503-516.

[31] Mendoza, E., 1991. Real business cycles in a small open economy. American Economic Review, 81(4), 797-818.

[32] Michaelides, A., 2002, Buffer stock saving and habit formation, London School of Economics Working Paper.

[33] Perri, F., Neumeyer, A., 2005. Business cycles in emerging economies: the Role of interest rates. Journal of Monetary Economics 52(2), 345-380.

[34] Pintus, P., Wen, Y., 2008. Excessive demand and boom-bust cycles. Federal Reserve Bank of St. Louis Working Paper.

[35] Ryder, H., Heal G., 1973. Optimal growth with intertemporally dependent preferences. Review of Economic Studies 40(1), 1-31.

[36] Tugan-Baranovsky, M., 1894. Industrial crises in contemporary England, their causes and immediate consequences on National life. (In russian). I. Schorochodov.

[37] Wen, Y., 2009, An analytical approach to buffer-stock saving. Federal Reserve Bank of St. Louis Working Paper.

[38] Wicksell, K., 1898. Interest and Prices. New York: Augustus M. Kelley.

[39] Wicksell, K., [1906] 1935, Lectures on political economy, Vol.2. Lionel Robbins Ed. London: Routledge and Sons. 